\title{
AFRICAN OPINION
}

It is obvious that the wild life of Africa can only survive if Africans take an interest in its survival. But some Europeans hold that Africans have little such interest, or even take the extreme view that it is impossible to arouse their interest. To show that there is no need for this pessimism, we reproduce below a copy of a letter received by Dr. E. B. Worthington, Chairman of I.U.C.N. African Special Project 1960-63, from Mr. H. S. Mahinda. Mr. Mahinda, who is partly a Masai, has been transferred to the headquarters of the Tanganyika Game Department to enlighten Africans in the purpose and practice of nature conservation.

$$
\begin{gathered}
\text { Dar-es-Saldam, } \\
\text { 8th July, } 1960 .
\end{gathered}
$$

Dear Dr. Worthington,

I remember to have been promised writing to you a letter and inform you how I am getting on with my new work of publicity.

From 7th April this year I started to go out and give talks to Barazas, Chiefs, Politicians, Church-Ministries, Muslin Sheikhs and Institutions. It is very encouraging to see that not only men or school boys who took interest in my talk about game, but Headmistresses and school girls as well. However, I have not yet come across any opposition except that sometimes people asked me questions so that they can know much and I am glad that I have been able to answer them according to their satisfaction.

As a beginning I am also very pleased to see that many Africans especial politicians and religion-leaders have been very kind to me by helping to give me some good advices on my work. The advices given by Provincial Secretary of T.A.N.U. (Tanganyika African National Union) at Morogoro was very similar to yours but unfortunately while $I$ was working in Morogoro district I had not been thinking of giving out my book to people to write in their comments. At the moment I cannot predict anything concerning the future of wild life but there will be a time for me to do so.

The attached is a brief note of my lectures to schools and pamphlets in which the most part of it written on game conservation have been originated in my views.

During the month of April there was very heavy rain all over the country and most roads were closed down for vehicles to pass, 
but now everything is free. Everywhere people are very busy reaping their crops and we are expecting to get very heavy harvest this year. In some parts of Southern and Eastern Provinces lions have resumed again killing people for food. But as you know this very often happens in the countries which have very few animals to hunt and where animals have been killed off so carelessly, and as a result these lions now have turned out to feed on human beings, meat, to avoid dying of starvation.

I hope this is enough to make you tired. Excuse me for my broken English.

Yours sincerely,

H. S. Mahinda,

Game Assistant.

It is not necessary to reprint Mr. Mahinda's lecture notes but something of the value of his lectures can be learnt from the following comments :

\section{Tanga Secondary School}

Mr. H. S. Mahinda, Senior Game Scout, at present visiting Institutions giving lectures on the usefulness of wild life, gave two lectures to the Senior boys and the Junior boys of the Government Secondary School Tanga, on Tuesday, 7th June, and Thursday, 9th June, 1960.

These lectures have been very enlightening. Quite a number of facts concerning wild life and the value the country derives from these Natural Resources of a country, which the boys were totally ignorant about were brought to light. Personally I do feel that such visits should take place from time to time so that the boys get to know facts not included in their school curriculum.

G. Mkwawa,

Master.

Government Midde School, Kisosora

The lecture was very interesting and many things have been learnt which were not known before by almost all the pupils.

The two main points-

(a) Prevention of cruelty to animals.

(b) Game is a Natural Resource of the Country.

All were thankful and pleased. I assure that it was a marvellous lecture which I liked very much.

D. Kibwana, Headmaster. 


\section{Tanga Girls' School}

Mr. Mahinda visited the Tanga Girls' School on Wednesday, 8 th June, 1960, to give his lecture on wild game to the girls.

He spoke for an hour to the whole school and both the younger and older ones were very interested-he was able to hold their interest throughout by the amusing way he explained simple facts about Game in Tanganyika.

We should like to see other departments following the example of the Game Department in sending competent lecturers.

\section{Files,}

\section{Headmistress, Government Girls' School, Tanga.}

\section{Government Middle School, Martin Shamba}

Mr. Mahinda visited the school and gave a lecture about Game animals. The whole school gathered together in the dining hall and listened to him. He spoke for almost one hour. His lecture was very interesting and useful.

Many sensible questions were asked by these town boys who very seldom see such animals and were answered satisfactorily.

Many thanks to the Game Department for arranging such a visit. The lecture started at 11 a.m. and ended at 12 noon on 13th June, 1960.

\section{Martin Akida,} Headmaster.

\section{Middle School, Pongwe}

Mr. Mahinda visited this school on 13th June, 1960.

He gave a lecture to the pupils on (a) The work of Game Department. (b) Uses of wild animals. (c) How to increase the number of wild animals. (d) Why sometimes wild animals catch human beings. (e) What steps should one take when he wants to hunt wild animals. $(f)$ How wild animals should be treated. (g) Kinds of Licences. ( $h$ ) Amount of money collected last year by selling tusks, skins, etc.

The pupils took great interest in the lecture and asked sensible questions. Both the staff and pupils appreciated his visit and would be pleased to see him again in our school.

\section{G. Athumani, Headmaster.}

Mr. Mahinda has met me and explained to me all that he is doing towards animals. I have really appreciated his action. Animals are beings to be treated kindly. This is even sujported 
by Islams. There are many sayings from Prophet Mohamed testifying that and the Quran itself testifies that too. I have willingly subscribed to him some sayings of prophet and a verse of the Quran to show that Islams do regard animals as creatures to be cared and guarded.

Mohamed Bin Sheikh Ali Hamed, Tanga.

Further light is thrown on this matter by the following extract from a letter from Mrs. Isobel Slater, M.B.E., Director, Tanganyika Division, Royal Society for the Prevention of Cruelty to Animals.

" The primary work of any S.P.C.A. is, of course, prevention of cruelty, but in a country such as this, cruelty cannot be prevented unless ignorance is removed in the first instance. So with that object in view, I made it a specialized job over many, many years, to bring education in animal welfare into the lives of the African people, all the time using a kindly and personal approach. The result of all this patient persuasion is clearly in evidence to-day - thousands of Africans follow the teaching received and actively spread the lessons learned over every area of the country. I have trained Africans during the past few years to become organizers in animal welfare, and these young men will be able to carry on the work of this Society in the days to come. Any project* for the protection of Wild Life will have a solid backing from African members of this Society, given the chance to take part in it. I know also many African chiefs who are keen for the protection of wild life, but all wait until somebody starts first!

I am amazed that such an inaccurate impression of the attitude of Africans towards wild life should have got around. Africans generally speaking are innately drawn towards animals - animals being part of their domestic lives - but ignorance remains and unless the needs of animals are brought to people's attention, the animals will suffer through a lack of moral understanding."

* Mrs. Slater is referring to the I.U.C.N. Africa Special Project 1960-63. 